\title{
Trends in the Development of University Education in the Postmodern Period
}

\author{
Ellina A. Panasenko \\ Donbas State Pedagogical University \\ Oksana A. Zhukova \\ V.N. Karazin Kharkiv National University \\ Tetiana V. Nekrashevych \\ Kharkiv National Medical University \\ Hanna H. Tsvietkova \\ National Pedagogical Dragomanov University \\ Yaroslava V. Shvedova \\ V.N. Karazin Kharkiv National University
}

The purpose of the research was to study the changes in the ranking of professional skills of students, which determine trends in university education in the postmodern era. The presented results of the experiment allowed to determine the level of perception of new professional skills by university students under the influence of the ideology of postmodernism. The general hypothesis of the study was that postmodern ideology influences the model of university education, contributes to the creation of the foundations for the formation of new professional skills of students. This study is part of a broader study that explores ways to improve the quality of university education based on the substantive professional priorities of students in the context of postmodernism. The results of the experiment allowed us to draw conclusions about the relationship between the quality of education and professional priorities of students, a properly organized system of university education in the postmodern period.

Keywords: student, professional skill, study, teacher, ideology

\section{INTRODUCTION}

Postmodern ideology, as a formative idea of the development of university education in Europe, has long united scientists and researchers at least in an effort to understand and interpret the conceptual changes taking place in higher education today (Science education for..., 2015; Country report Romania, 2019). First, it is worrying to find ways to better conceptualize and understand what is happening in university education now, in terms of activating distance forms of work (Bayram-Jacobs, 2015; Huidu, 2018; Zhernova, 2018; Mirḳe et al., 2019). One of the priority areas of research is to find ways to effectively 
develop professional skills in the postmodern era: from the use of high-tech forms of education (Mason, 2006) to the formation of a new educational ideology and ecology of education (Köktürk, 2012; Salgur, 2013). Also relevant is the search for effective management solutions on how to properly manage in a rapidly changing situation in university education (Melia et al., 2020). It is worth realizing the place of higher education in society, its own effectiveness and usefulness. Modern pedagogy also considers the question of how to impose properly postmodern methods and techniques to traditional university education (Kelly, 2002; Kiki-Papadakis and Chaimala, 2016). In addition, this is an excellent conceptual research problem.

The scientific problems of the research are determined by the discussion on the directions of development and reform of the university education system (Hryniak et al., 2021; Sitsinska et al., 2021). There is a widespread perception of the need for radical change as the number of universities increases, and so does the number of teachers and students. And it also has consequences: an endless discussion about changing higher education standards and a lack of the necessary resources. That is why the concept of "postmodern university" is so relevant now (Kelly, 2002; Voinea, 2012) and identify the leading directions of the movement of university education, it is necessary to identify the tools that will help to better see the development trends and the concept of the existence of a modern university as an educational institution (Damian et al., 2017).

There is a definition of new curriculum skills, formed under the influence of the ideology of postmodernism, as well as the study of changes in the ranking of professional skills of students that determine trends in university education in the postmodern era.

Research tasks:

- definition of new program skills of higher education seekers, formed in the ideology of postmodernism;

- research and formation of a rating of professional skills of students in the postmodern era;

- comparison of the content and main features of "traditional" university education and education of the postmodern era.

The development of European university education in postmodernism is defined by a number of areas (Science education for..., 2015; Country report Romania, 2019; World Economic Forum, 2020). In fact, as a phenomenon, it began to be actively studied in the 90s (Herrera et al., 2020). After that, a number of issues were outlined that required constant monitoring, discussion and provoked lively discussions in the pedagogical community. The problems of multiculturalism in education and economics (Holovaty, 2014); cultural contexts and contradictions in modern education (Fritz et al., 2002); Marxism, feminismand other ideologies in the development of education in the postmodern period (Kelly, 2002; Synorub and Medynska, 2019); technologicalization of learning in the era of postmodernism (Dzvinchuk et al., 2020). A number of researchers in the field of higher education have identified such a core characteristic of the postmodern side of education - this is one of the forms of the most convenient and comfortable human condition, even in crisis and stress (Ivanova et al., 2020; Ramirez-Leal, 2020). Gender issues in university education also were studied. J. Kelly (2002) considers feminism one of the distinguishing features of the postmodern period. In the two manifestations of feminist currents (poststructuralist and postmodern) in education there are positive directions of development - it addresses a number of issues related to pay and education, learning conditions and effective management measures in education that will improve women's rights in universities. The negative feature is the tendency to excessive theorizing, inconsistency in the theory and implementation of ideas, lack of systematic approaches (Kelly, 2002; Voinea, 2012).

\section{LITERATURE REVIEW}

In the postmodern educational movement there are a number of changes in curricula, methodological approaches to learning, pedagogical practice, caused by social and educational ideas of a postmodern nature (Boghian, 2019; Čuhlová, 2019). First of all, it is a question of abandoning traditional forms of education, changing the worldview paradigm, where social control becomes the main thing. Such an approach requires moderation and a return of emphasis from the search for meaning in educational discourse to critical action, 
where the main emphasis is on politics, the economics of education. Although can not refuse to pay attention to the cultural and educational processes of modern social and educational life. A separate analysis of the success of educational reforms over the past ten years, which are based on postmodern educational ideology (Lalak and Hrab, 2020).

D. Bayram-Jacobs (2015) and S.A. Salgur (2013) examine changes in higher education, namely its positive and negative aspects. A positive feature is the dynamism that gives postmodernism, entrepreneurial spirit that has returned to the education system, when the classical approach is formalized, bureaucratic and unable to respond quickly to challenges, to use all the opportunities offered by the modern world. This is primarily a study of ways to introduce funding for new projects, courses and commercially profitable specialties. Researchers (Fossatti et al., 2020; Kuzmina et al., 2020), who are supporters of this position; recognize that the use of innovation in the management structures of the university allows to attract commercial practices that sometimes significantly change academic traditions. The downside of this is the lack of long-term planning, and the gap, which is sometimes formed between the demands of university youth and the needs of employers, as well as the pressure of auditors, the constant search for the ideal value for money. All this brings inconsistencies in the processes of modernization of university education in the world of postmodern ideology.

The need to take into account the guidelines of postmodernism is also dictated by the crisis of university education in the 80-90s of the twentieth century. The golden age of European universities was in the 50's, when they had rich resources, students belonged to the elite, and routine and discriminatory principles were mostly dismantled (Bayram-Jacobs, 2015; Fossatti et al., 2020; Ivanova et al., 2020). Postmodernism has made more democratic and high-quality interaction between teachers and students, encourages intellectual and creative efforts. One of the ideological guidelines presented by the concept of postmodernism is to focus on the influences of traditions, national, social, cultural identities of society (Savu, 2014; Kuzmina et al., 2020). That is an important guideline in the university education system today. The group of researchers claims that the traditions of politeness and cooperation of tolerance are instilled as a moral guide for the student, with their help not only the educational system, but also modern postmodern society as a whole.

An important feature of postmodern approaches is the granting of greater autonomy to universities (Fossatti et al., 2020; Mostepaniuk, 2020; Nepomnyashchyy et al., 2021). This facilitates access to education for minority groups, socially vulnerable and discriminated groups by sex, race, and origin. There is also a constant search for ways to reduce the cost of education for privileged categories. Scientific research testifies to the development of postmodern educational technologies, which have a wide range of problems: technologicalization of education, wide access and quality of knowledge, national education, gender and social issues, prospects for development and improvement of university policies to adapt education to modern society participants in the educational process. In the context of the purpose of the study, the question of the development of university education in the context of the ideology and ideological foundation of postmodernism remains open.

\section{MATERIALS AND METHODS}

The online survey method was used in Wyższą Szkołą Gospodarki Euroregionalnej im. Alcide De Gasperi (Józefów, Poland) among senior students of humanities. It was used during the 1st and 2nd semesters of the 2019-2020 academic year (October 2019 - April 2020) using Google Drive forms. The proposed study is a logical continuation of previous experiments, which are the result of previous research programs (Boghian, 2019), as well as based on similar experimental studies close to the topic proposed in the article (Synorub and Medynska, 2019; Ivanova et al., 2020). Given the presented context, possible correlations between the level of readiness to change the priorities of higher education students and the respondents' perception of changes in educational content, postmodern settings for new programming skills (World Economic Forum, 2020) and learning experience in the personal educational paradigm (Rababah, 2020) were investigated (World Economic Forum, 2020).

The proposed intelligence is of a research nature, so the method of observation was used as an empirical method, which allowed to determine directly the pedagogical phenomenon and systemic changes that occur 
during a particular process (learning). The empirical method is involved in order to determine the ranking of top-15 skills in different study groups with different methodological and ideological guidelines. The research methodology involved a number of methods such as survey method, statistical methods (qualitative and quantitative), mathematical methods, as well as a combination of analytical methods (deductive and inductive), the use of questionnaires and observations, etc. The sample consisted of 140 students of various specialties of the humanities Wyższą Szkołą Gospodarki Euroregionalnej im. Alcide De Gasperi (Józefow, Poland). All respondents were grouped into several groups with similar specialties and professional needs, experience, with the same level of education and attended a program on information security and pedagogical training for pedagogical practice.

There were 70 respondents (group 1 - hereafter G1) who preferred the block of subjects of the humanities cycle according to the new modernized educational program and with the application of postmodern methods, content and form in teaching. Disciplines in the curriculum, teaching methods and specialized professional practices were included in the curriculum. This was based on the opinion of students, which was established through regular surveys. There were 70 respondents (group 2 - hereafter G2) who chose a block of subjects of the humanities cycle according to traditional classical university methodological recommendations, content and practical content of courses. By filling out the questionnaires, respondents agreed to participate in the survey. Throughout the experiment, the research team adhered to the ethical principles of the study, and the data collected on the basis of the questionnaire provided for the preservation of the dignity and privacy of the participants. The study was observational and did not contain non-invasive interventions, no measures were taken that would affect the openness and honesty of the participants, experiment also involved compliance with the interests of respondents.

The questionnaires compiled for the implementation of the research goal were adapted to the Polish version of the new education system, the list of new program skills of the new university education (Science education for..., 2015; Country report Romania, 2019). Top-15 skill items in the list, which provides the ability to distribute points according to the level of importance according to the level of diminishing importance of each program skill (World Economic Forum, 2020). That is, the most important is placed on the 1 st place, the least valuable, according to respondents, is placed on the 15 th place. Some evaluation items had to be changed at the stage of calculating priorities, as sometimes the ratings contained statements about the constructive influences of certain disciplines, characteristics of curricula, level of satisfaction with the quality of education, attempts to avoid stereotypes and so on.

The survey of respondents was conducted in 4 stages. Stage 1 . Assessment of the priority for students of new program skills before the educational process. Stage 2. End of the first semester. The middle of the experiment. Monitoring changes in the ranking of top-15 skills. Stage 3. Determination of final rating positions in 2 groups at the end of the school year. Stage 4. Determining the changes that have occurred in the ratings during the school year. Disadvantages and difficulties observed during the experiment: the reasons for preferences (choices) are not identified, it takes a long time (during the academic year (2 semesters), the researcher takes a passive position of an observer, it is not possible to conduct in-depth qualitative research. Both qualitative and quantitative approaches were used to establish and compare the frequency of responses and transform it into ranking items, and respondents agreed to participate in the survey, and their anonymity was maintained.

\section{RESULTS}

In order to test the hypothesis about the influence of postmodern ideologically methods and ways of organizing university education on the perception of students directly in the learning process, it is necessary to join the test of this hypothesis. To test, authors used the top-15 professional skills according to the version World Economic Forum and Education Development Strategy in the European Union, by offering them to students for assessment in 4 stages during the academic year. Respondents were grouped into two groups (G1 and G2), both chose two learning strategies and, accordingly, forms and methods of learning with the same curriculum. The evolution in the awareness of the proposed new professional skills of G1 education can be seen in the changes in the ranking relative to G2, which are presented in a separate column. Authors 
do the same for G2: identifying and quantifying the rating of skills that illustrate the desire to interact constructively (Table 1).

TABLE 1

STAGE 1. RATING OF NEW SOFTWARE SKILLS

\begin{tabular}{|c|c|c|c|c|c|c|}
\hline No & Top-15 skills & $\begin{array}{l}\text { G } 1 \text { (place } \\
\text { in the } \\
\text { ranking) }\end{array}$ & $\begin{array}{l}\text { Rating } \\
\text { changes }\end{array}$ & $\begin{array}{l}\text { D } 2 \text { (place } \\
\text { in the } \\
\text { ranking) }\end{array}$ & $\begin{array}{l}\text { Rating } \\
\text { changes }\end{array}$ & $\begin{array}{l}\text { The } \\
\text { difference } \\
\text { between the } \\
\text { groups }\end{array}$ \\
\hline 1 & $\begin{array}{l}\text { Analytical thinking and } \\
\text { innovation }\end{array}$ & 5 & -1 & 4 & +1 & 1 point \\
\hline 2 & $\begin{array}{l}\text { Active learning and learning } \\
\text { strategies }\end{array}$ & 13 & +1 & 14 & -1 & 1 \\
\hline 3 & Solving of complex problems & 1 & - & 1 & - & - \\
\hline 4 & Critical thinking and analysis & 6 & +3 & 9 & -3 & 3 points \\
\hline 5 & $\begin{array}{l}\text { Creativity, originality and } \\
\text { initiative }\end{array}$ & 2 & +1 & 3 & -1 & 1 point \\
\hline 6 & $\begin{array}{l}\text { Leadership and social } \\
\text { influence }\end{array}$ & 8 & -3 & 5 & +3 & 3 points \\
\hline 7 & $\begin{array}{l}\text { Use of technology, monitoring } \\
\text { and control }\end{array}$ & 7 & +1 & 8 & -1 & 1 point \\
\hline 8 & $\begin{array}{l}\text { Technology design and } \\
\text { programming }\end{array}$ & 9 & -3 & 6 & +3 & 3 points \\
\hline 9 & $\begin{array}{l}\text { Stability, stress resistance and } \\
\text { flexibility }\end{array}$ & 3 & -1 & 2 & +1 & 1 point \\
\hline 10 & $\begin{array}{l}\text { Argumentation, problem } \\
\text { solving and the ability to form } \\
\text { ideas }\end{array}$ & 10 & +2 & 12 & -2 & 2 points \\
\hline 11 & Emotional intelligence & 11 & +2 & 13 & -2 & 2 points \\
\hline 12 & $\begin{array}{l}\text { Problem solving and user } \\
\text { interaction }\end{array}$ & 12 & -1 & 11 & +1 & 1 point \\
\hline 13 & $\begin{array}{l}\text { Focus on service and } \\
\text { maintenance }\end{array}$ & 15 & - & 15 & - & 1 point \\
\hline 14 & $\begin{array}{l}\text { System analysis and } \\
\text { evaluation }\end{array}$ & 4 & +3 & 7 & -3 & 3 points \\
\hline 15 & Negotiation & 14 & -4 & 10 & +4 & 3 points \\
\hline
\end{tabular}

Source: developed by the authors.

Rating Table 1 differs in the first and second groups. Definition of software skills: "Negotiation", "Systems Analysis and Evaluation", "Technology Design and Programming", "Leadership and Social Impact", "Critical Thinking and Analysis" were assessed by groups with a difference of 3-4 points: for G1 critical analysis and systems analysis are important and evaluation. The first three places in the ranking belong to G1 - "Solving complex problems" (1st place), "Creativity, originality and initiative" (2nd place), "Sustainability, stress and flexibility" (3rd place). The championship in G2 is given to "Stability, stress resistance and flexibility" (2nd place), common with G1 is the first position in solving complex problems; then "Creativity, originality and initiative" are defined as 3rd place. The last places are given in G 1 ability to negotiate (14th position) and focus on service and maintenance (15th position) - G1. G2 defined "Active learning and learning strategies" (14th position). There is no difference in the rating in the assessment of 
the group's ability to focus on the provision of service and maintenance - it is 15 th place in the ranking (last) (Table 2).

TABLE 2

STAGE 2. DETERMINING THE RATING OF NEW PROGRAM SKILLS AT THE END OF THE FIRST SEMESTER IN G1 AND G2

\begin{tabular}{|c|c|c|c|c|c|c|}
\hline No & Top-15 skills & $\begin{array}{l}\text { G } 1 \text { (place } \\
\text { in the } \\
\text { ranking) }\end{array}$ & $\begin{array}{l}\text { Rating } \\
\text { changes }\end{array}$ & $\begin{array}{l}\text { D } 2 \text { (place } \\
\text { in the } \\
\text { ranking) }\end{array}$ & $\begin{array}{l}\text { Rating } \\
\text { changes }\end{array}$ & $\begin{array}{l}\text { The difference } \\
\text { between the } \\
\text { groups }\end{array}$ \\
\hline 1 & $\begin{array}{l}\text { Analytical thinking and } \\
\text { innovation }\end{array}$ & 5 & - & 5 & - & \\
\hline 2 & $\begin{array}{l}\text { Active learning and learning } \\
\text { strategies }\end{array}$ & 15 & -1 & 14 & +1 & 1 point \\
\hline 3 & Solving of complex problems & 1 & +1 & 2 & -1 & 1 point \\
\hline 4 & Critical thinking and analysis & 7 & +1 & 8 & -1 & 1 point \\
\hline 5 & $\begin{array}{l}\text { Creativity, originality and } \\
\text { initiative }\end{array}$ & 2 & +1 & 4 & -2 & 2 points \\
\hline 6 & $\begin{array}{l}\text { Leadership and social } \\
\text { influence }\end{array}$ & 8 & -2 & 6 & +2 & 2 points \\
\hline 7 & $\begin{array}{l}\text { Use of technology, } \\
\text { monitoring and control }\end{array}$ & 6 & +3 & 9 & -3 & 3 points \\
\hline 8 & $\begin{array}{l}\text { Technology design and } \\
\text { programming }\end{array}$ & 9 & -2 & 7 & +2 & 2 points \\
\hline 9 & $\begin{array}{l}\text { Stability, stress resistance } \\
\text { and flexibility }\end{array}$ & 3 & -2 & 1 & +2 & 2 points \\
\hline 10 & $\begin{array}{l}\text { Argumentation, problem } \\
\text { solving and the ability to } \\
\text { form ideas }\end{array}$ & 10 & -1 & 11 & +1 & 1 point \\
\hline 11 & Emotional intelligence & 11 & +2 & 13 & -2 & 2 points \\
\hline 12 & $\begin{array}{l}\text { Problem solving and user } \\
\text { interaction }\end{array}$ & 12 & - & 12 & - & \\
\hline 13 & $\begin{array}{l}\text { Focus on service and } \\
\text { maintenance }\end{array}$ & 14 & +1 & 15 & -1 & 1 point \\
\hline 14 & $\begin{array}{l}\text { System analysis and } \\
\text { evaluation }\end{array}$ & 4 & -1 & 3 & +1 & 1 point \\
\hline 15 & Negotiation & 13 & -3 & 10 & +3 & 3 points \\
\hline
\end{tabular}

Source: developed by the authors.

Rating Table 2 differs in the first and second groups. Definition of software skills:evaluated in groups with a difference of 3-4 points. Critical analysis, systems analysis and evaluation are more important for G1. The first place in the ranking belongs to G2 "Stability, stress resistance and flexibility". In G2 the second position is given to "Solving complex problems". G1 defined as the top of the rating "Solving complex problems", "Creativity, originality and initiative" in G1 takes 2nd place. The third position in the ranking in G2 is "Systems Analysis and Evaluation", while G1 defines 3rd place as "Sustainability, stress and flexibility". The last places are given in G 1 "Orientation on service and maintenance" (14th position), on 15th position G1 "Active learning and learning strategies". G2 defined "Active Learning and Learning Strategies" as the 14th position in the ranking. In the G2 score "Service and service orientation" is the 15th place (the last of the top-15) (Table 3). 
TABLE 3

STAGE 3. DETERMINING THE RANKING OF NEW SOFTWARE SKILLS AT THE END OF THE FIRST SEMESTER IN G1 AND G2

\begin{tabular}{|c|c|c|c|c|c|c|}
\hline No & Top-15 skills & $\begin{array}{l}\text { G } 1 \text { (place } \\
\text { in the } \\
\text { ranking) }\end{array}$ & $\begin{array}{l}\text { Rating } \\
\text { changes }\end{array}$ & $\begin{array}{l}\text { D } 2 \text { (place } \\
\text { in the } \\
\text { ranking) }\end{array}$ & $\begin{array}{l}\text { Rating } \\
\text { changes }\end{array}$ & $\begin{array}{l}\text { The } \\
\text { difference } \\
\text { between the } \\
\text { groups }\end{array}$ \\
\hline 1 & $\begin{array}{l}\text { Analytical thinking and } \\
\text { innovation }\end{array}$ & 3 & +1 & 4 & - & 1 point \\
\hline 2 & $\begin{array}{l}\text { Active learning and learning } \\
\text { strategies }\end{array}$ & 15 & -1 & 14 & +1 & 1 point \\
\hline 3 & Solving complex problems & 4 & +2 & 2 & -2 & 2 points \\
\hline 4 & Critical thinking and analysis & 8 & - & 8 & - & \\
\hline 5 & $\begin{array}{l}\text { Creativity, originality and } \\
\text { initiative }\end{array}$ & 1 & -1 & 5 & +4 & 4 points \\
\hline 6 & $\begin{array}{l}\text { Leadership and social } \\
\text { influence }\end{array}$ & 7 & -1 & 6 & +1 & 1 point \\
\hline 7 & $\begin{array}{l}\text { Use of technology, monitoring } \\
\text { and control }\end{array}$ & 5 & -3 & 8 & +3 & 3 points \\
\hline 8 & $\begin{array}{l}\text { Technology design and } \\
\text { programming }\end{array}$ & 9 & +2 & 7 & -2 & 2 points \\
\hline 9 & $\begin{array}{l}\text { Stability, stress resistance and } \\
\text { flexibility }\end{array}$ & 2 & -1 & 3 & +1 & 1 point \\
\hline 10 & $\begin{array}{l}\text { Argumentation, problem } \\
\text { solving and the ability to form } \\
\text { ideas }\end{array}$ & 10 & -1 & 11 & +1 & 1 point \\
\hline 11 & Emotional intelligence & 11 & +2 & 13 & -2 & 2 points \\
\hline 12 & $\begin{array}{l}\text { Problem solving and user } \\
\text { interaction }\end{array}$ & 12 & - & 12 & - & \\
\hline 13 & $\begin{array}{l}\text { Focus on service and } \\
\text { maintenance }\end{array}$ & 14 & +1 & 15 & -1 & 1 point \\
\hline 14 & System analysis and evaluation & 4 & +3 & 1 & -3 & 3 points \\
\hline 15 & Negotiation & 13 & - & 13 & - & \\
\hline
\end{tabular}

Source: developed by the authors.

Rating Table 3 in the first and second groups has different assessments of educational skills. The definitions of the top-15 were evaluated by groups with a difference of 3-4 points, although the number of sharp differences decreased (1st time 4 points and $2 \mathrm{~d}$ times the difference 3 points). "Creativity, originality and initiative" are more important for G1. For G2, it is "System Analysis and Evaluation". The second place is defined in G1 "Stability, stress resistance and flexibility", then G2 "Solving complex problems". On the 3rd place of the rating in G1 is "Analytical thinking and innovation", when G2 defined "Sustainability, stress resistance and flexibility". In 13th place G2 and G1 - "Negotiation". "Service orientation and service" in G1 is in 14th place, in G2 this skill - 15th place in the ranking. G1 "Active learning and learning strategies defined" as 15th place, and G2 as 14th (Table 4). 
TABLE 4

STAGE 4. IDENTIFICATION OF TENDENCIES TO CHANGES OF TOP POSITIONS OF RATING OF TOP-15 SKILLS DURING ACADEMIC YEAR

\begin{tabular}{|l|l|l|l|l|l|l|}
\hline & 1 ranking position & 2 ranking position & 3 ranking position \\
\cline { 2 - 7 } & D 1 & D 2 & D 1 & D 2 & D 1 & D 2 \\
\hline Stage 1 & $\begin{array}{l}\text { Solving of } \\
\text { complex } \\
\text { problems }\end{array}$ & $\begin{array}{l}\text { Solving of } \\
\text { complex } \\
\text { problems }\end{array}$ & $\begin{array}{l}\text { Creativity, } \\
\text { originality } \\
\text { and initiative }\end{array}$ & $\begin{array}{l}\text { Stability, } \\
\text { stress } \\
\text { resistance } \\
\text { and } \\
\text { flexibility }\end{array}$ & $\begin{array}{l}\text { Stability, } \\
\text { stress } \\
\text { resistance } \\
\text { and } \\
\text { flexibility }\end{array}$ & $\begin{array}{l}\text { Creativity, } \\
\text { originality and } \\
\text { initiative }\end{array}$ \\
\hline Stage 2 & $\begin{array}{l}\text { Solving of } \\
\text { complex } \\
\text { problems }\end{array}$ & $\begin{array}{l}\text { Stability, } \\
\text { stress } \\
\text { resistance } \\
\text { and } \\
\text { flexibility }\end{array}$ & $\begin{array}{l}\text { Creativity, } \\
\text { originality } \\
\text { and initiative }\end{array}$ & $\begin{array}{l}\text { Solving of } \\
\text { complex } \\
\text { problems }\end{array}$ & $\begin{array}{l}\text { Stability, } \\
\text { stress } \\
\text { resistance } \\
\text { and } \\
\text { flexibility }\end{array}$ & $\begin{array}{l}\text { System } \\
\text { analysis and } \\
\text { evaluation }\end{array}$ \\
\hline Stage 3 & $\begin{array}{l}\text { Creativity, } \\
\text { originality } \\
\text { and initiative }\end{array}$ & $\begin{array}{l}\text { System } \\
\text { analysis and } \\
\text { evaluation }\end{array}$ & $\begin{array}{l}\text { Stability, } \\
\text { stress } \\
\text { resistance } \\
\text { and } \\
\text { flexibility }\end{array}$ & $\begin{array}{l}\text { Solving of } \\
\text { complex } \\
\text { problems }\end{array}$ & $\begin{array}{l}\text { Analytical } \\
\text { thinking and } \\
\text { innovation }\end{array}$ & $\begin{array}{l}\text { Stability, } \\
\text { stress } \\
\text { resistance and } \\
\text { flexibility }\end{array}$ \\
\hline
\end{tabular}

Source: developed by the authors.

Table 4 on the priority in the ranking of educational skills in the first and second groups has different priorities. Definitions of the top-15 were evaluated by groups with a difference of 1-2 points, the number of sharp differences was small and indicates a clear awareness of the respondents of their professional priorities. Ratings changed during the school year in both groups. The changes were especially relevant to neighboring positions. There were no sharp transformations. The skill "Stability, stress resistance and flexibility" remained constant in the first positions. At the end of the training process, the skill "Solving complex problems" disappeared from the first places of the rating. The results obtained during the experiment will allow the administration in the future to plan the content and methodological content of training courses, curricula and measures to create success and professional growth of students (Table 5).

TABLE 5

\section{IDENTIFYING TRENDS IN THE LAST POSITIONS OF THE TOP-15 SKILLS RATING DURING THE SCHOOL YEAR}

\begin{tabular}{|l|l|l|l|l|l|l|}
\hline \multirow{2}{*}{$\begin{array}{l}\text { Stage } \\
\text { No }\end{array}$} & 13th position of the rating & \multicolumn{2}{|l|}{ 14th position of the rating } & \multicolumn{2}{l|}{ 15th position of the rating } \\
\cline { 2 - 7 } & D 1 & D 2 & D 1 & D 2 & D 1 & D 2 \\
\hline Stage 1 & $\begin{array}{l}\text { Active } \\
\text { learning and } \\
\text { learning } \\
\text { strategies }\end{array}$ & $\begin{array}{l}\text { Emotional } \\
\text { intelligence }\end{array}$ & $\begin{array}{l}\text { Ability to } \\
\text { negotiate }\end{array}$ & $\begin{array}{l}\text { Active } \\
\text { learning and } \\
\text { learning } \\
\text { strategies }\end{array}$ & $\begin{array}{l}\text { Focus on } \\
\text { service and } \\
\text { maintenance }\end{array}$ & $\begin{array}{l}\text { Focus on } \\
\text { service and } \\
\text { maintenance }\end{array}$ \\
\hline Stage 2 & Negotiation & $\begin{array}{l}\text { Emotional } \\
\text { intelligence }\end{array}$ & $\begin{array}{l}\text { Focus on } \\
\text { service and } \\
\text { maintenance }\end{array}$ & $\begin{array}{l}\text { Active } \\
\text { learning and } \\
\text { learning } \\
\text { strategies }\end{array}$ & $\begin{array}{l}\text { Active } \\
\text { learning and } \\
\text { learning } \\
\text { strategies }\end{array}$ & $\begin{array}{l}\text { Focus on } \\
\text { service and } \\
\text { maintenance }\end{array}$ \\
\hline Stage 3 & Negotiation & Negotiation & $\begin{array}{l}\text { Focus on } \\
\text { service and } \\
\text { maintenance }\end{array}$ & $\begin{array}{l}\text { Active } \\
\text { learning and } \\
\text { learning } \\
\text { strategies }\end{array}$ & $\begin{array}{l}\text { Active } \\
\text { learning and } \\
\text { learning } \\
\text { strategies }\end{array}$ & $\begin{array}{l}\text { Focus on } \\
\text { service and } \\
\text { maintenance }\end{array}$ \\
\hline
\end{tabular}

Source: developed by the authors. 
The postmodern approach involves the acquisition of knowledge through persuasion and understanding, not under pressure, but through simplicity, clarity and clarity, leading to consensus (agreement, unity), ie the student can see, reflect, share and accept the position of the teacher independently, at will and consciously. The ultimate goal of such an educational process should be to encourage students to cooperate, act together and identify teachers and students, only then communication (communication process, learning) will be more successful and effective. This is the kind of university education that takes into account the postmodern space of society. Below present a clear comparison of the traditional model of university education and education in the period of modernism (Figure 1).

\section{FIGURE 1 \\ THE DIFFERENCE OF APPROACHES BETWEEN TRADITIONAL AND POSTMODERN MODELS OF EDUCATION}

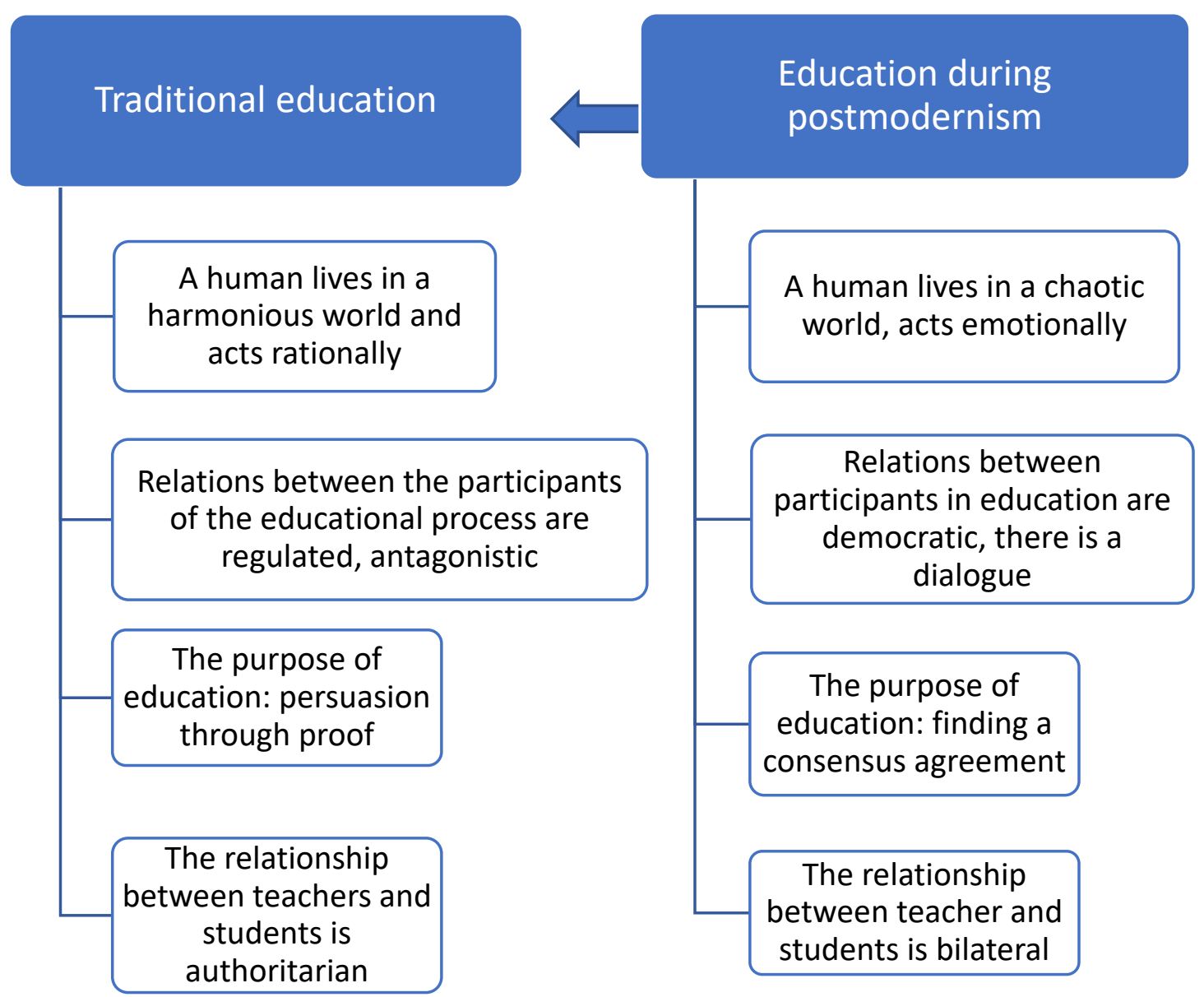

Source: developed by the authors.

As shown in Figure. 1. One of the main positions in postmodern approaches to university education is the attempt to join ech participant in the educational process to an active position, ideology of democratic society and free choice in it - finding their place and role in the "chaotic world" of requests and proposals. This is possible provided that the scientific and pedagogical staff has authority, personal and social, and the task of students in this context - should be to understand the guidelines of university education even better than its ideologues and managers. Through dialogue, all participants in the educational process overcome the limitations of depersonalized traditional education with its objective logic of reasoning, which, after the involvement of postmodern educational guidelines, make university education more individualized, 
democratic, personal in content and forms. The relationship between teachers and applicants is based on valuable information, as the belief in postmodern education is achieved not only by the power of proof, the provision of large amounts of factual information, but the exchange of values, knowledge and motivation. In the postmodern approach to education, the moment of complicity, active involvement of all participants in the learning moment is also important, where the ultimate form is empathy, where the learner puts himself in the place of the teacher and vice versa. Thus, in the process of deep understanding of the essence of the educational process and the material of teaching, both the teacher and the students identify each other and then an effective educational process becomes possible.

\section{DISCUSSION}

Authors (Voinea, 2012; Köktürk, 2012), based on the theory of the hierarchy of needs, determine the main obstacle to education is that a person as such does not move towards self-realization - and this is an important consequence of society. Success in this context is interpreted as the degree of success in terms of abilities and professional interests of man. In the context of "postmodern education", the importance of students' aspirations for professional skills and support by universities for the educational needs and interests of students should be recognized as a positive reaction and encouragement to self-realization. The university should become a unique educational environment that provides such an atmosphere. The entire teaching and administrative staff should contribute to the success of students. The administration must constantly monitor and analyze the level of effectiveness of assistance in student performance, take into account the ratings when forming the strategy of university development. It also makes administration more efficient, enables the proper formation of organizational and educational culture, determines planning and ensures the future of university education.

Similar studies were conducted in the 2018/2019 academic year (Ivanova et al., 2020), where an experimentally determined effective postmodern technique of implementation of activities, social work based on intercultural exchange of students of media in Poland, Ukraine and Asia. Such activities contributed to increasing the efficiency of the initial process, further employment of the participants of the experiment (trainees and United Nations (UN) staff, news programs on television and radio, etc.) Researchers also rightly point out that sometimes theoretical statements and policies, practical side, wellthought-out strategy are left aside (Ivanova et al., 2020), where the teacher does not authoritarianly instill their own opinions and beliefs woven into educational information, but step by step in alliance with students opens, proves its position, "wrapped" in educational information and skills. Many scholars criticize such teaching methods for changing the ideological vectors of modern education (Kelly, 2002; Huidu, 2018). In fact, at the level of moral and ethical evaluation, the philosophy of modern university education coincides with the philosophy manifested in postmodernism. Sometimes such pedagogical activity is interpreted as a manifestation of emotional violence, imposition of thought (manipulation, invisible control of a person) (Kelly, 2002; Fossatti, 2020). However, the foundation of new education is the approach to the person as a student as a consumer of the educational product.

The postmodern notion of consensus implies a certain departure from authoritarian forms of education, because it is in the range of "persuade - give the opportunity to learn" (Denyskina et al., 2020). M. Voinea (2012) for several years explored the relationship between competency approaches in higher education and the level of intercultural communication opportunities of urban and rural learners, students' assessment of the quality and modernity of the educational process in the context of openness to new forms and methods of teaching. The study of multicompetence V. Illman and P. Pietilä (2018) is conducted with a simultaneous survey of both students and teachers, while this study focused only on the results of student surveys to identify their professional priorities in the learning process. As the disadvantages of the traditional approach of universities to education, to the guidelines of modern civilization is that the guidelines proclaimed by them and developed educational positions today do not always look convincing and are effective. A group of researchers (Voinea, 2012; Savu, 2014; Ivanova et al., 2020) noticed this property and pointed out that the linear presentation of educational information in itself no longer has the force of influence, is not effective in the modern educational process. After all, the logic of teaching, in this context, is nothing more 
than a series of judgments, facts, formulas, and so on. This is not acceptable in the postmodern period, where traditional techniques are lacking. It is necessary to constantly seek common ground, openness and accessibility of the educational process, but such an approach requires some training and intellectual strength of the audience.

University education in the postmodern period should present to students the full potential of the academic environment, improve the conditions of students' adaptation to organizational culture while ensuring professional stability, educational stability, thus maintaining students' satisfaction with the declared program results, support student success (Kuzmina et al., 2020; Lu, 2020). Trying to follow the interests of students promotes adaptation to academic and social experience in society through the ranking of organizational culture and institutional environment. All these are components of the stability of education, which is not in the traditionalism of academia, but in the satisfaction of participants in the educational process in the course, form and results of learning. This will keep university education at a high communicative level and present it with dignity in the technological market of education.

\section{CONCLUSIONS}

The university administration should form a strategy for the future development of the institution and, in accordance with the request of society, form the content and content of university education. One of the priorities in the development of business strategies is monitoring, in particular questionnaires and prioritization of students' professional skills. This approach will ensure the institutional effectiveness of university education in the context of the development of society in the postmodern period. The processes of transformation that take place in society affect the educational environment and the activities of higher education institutions, and the involvement of students in the formation of development strategies of the university creates in them a sense of belonging to the educational process. Regular monitoring of students' vision of the content and quality of future education determines the educational trajectory of the university,

Postmodernism has a set of ideological guidelines and solutions that can be used in the theory and practice of university education. Modern participants in university education, and especially management staff, at all levels should be equally focused on strategies that will ensure a successful learning process. Thus, postmodernism is an important factor in the future of higher education as well as strategic administration. The experiment showed that the application of the ideological guidelines of postmodernism in university education, makes education close to the needs of modern society, helps to develop professional skills. The experience of such observations can be used as another way to keep students in university education. The results of the experiment will allow university managers to strategically plan the purpose, content and goals of education, focusing on the ranking of new program skills, compiled directly with the education of European universities. Conducting such experiments will allow to form a modern strategic development plan, which determines the prospects for further research and experiments in the postmodern context. The proposed study provides university institutions with recommendations for planning the work of the administration in the conditions of postmodernism.

\section{REFERENCES}

Bayram-Jacobs, D. (2015). RRI: What is it? How to integrate in science education. International Congress on Education for the Future: Issues and Challenges. Retrieved from https://www.researchgate.net/publication/279204567_RRI_What_is_it_How_to_Integrate_in_Sci ence Education

Boghian, I. (2019). Empowering teachers to deal with classroom diversity. Revista Romaneasca Pentru Educatie Multidimensionala, 11(3), 1-10.

Čuhlová, R. (2019). Intercultural adaptation process and its determinants. International Journal of Economics, Finance and Management Sciences, 7(6), 215-221. 
Damian, S.I., Iliescu, D.B., Rohozneanu, A., Glodeanu, A., Diac, M., David, S., \& Hunea, I. (2017). The role of educational measures for juvenile offenders in forensic psychiatry. Revista Românească pentru Educaţie Multidimensională, 9(3), 140-155.

Denyskina, G., Lysytskaia, E., Aleksandrova, M., \& Ivanova, I. (2020). Postmodernism as an artistic dominant in present-day Eastern European advertising. Journal of Critical Reviews, 7(9), 18391849.

Dzvinchuk, D., Radchenko, O., Kachmar, O., Myskiv, I., \& Dolinska, N. (2020). Analysis of platforms and tools of open study in the conditions of postmodern education. Revista Romaneasca Pentru Educatie Multidimensionala, 12(3), 125-143.

European Commission. (2015). Science education for responsible citizenship. Retrieved from $\mathrm{http} / / /$ ec.europa.eu/research/swafs/pdf/pub_science_education/KI-NA-26-893-EN-N.pdf

European Commission. (2019). Country report Romania. Retrieved from https://ec.europa.eu/info/ sites/info/files/file_import/2019-european-semester-country-report-romania_en.pdf

Fossatti, P., Monticelli, J.M., Danesi, L.C., \& Jung, H.S. (2020). Limits of sustainability management at community universities. Fronteiras, 9(3), 33-54.

Fritz, W., Mollenberg, A., \& Chen, G.M. (2002). Measuring intercultural sensitivity in a different cultural context. Intercultural Communication Studies, 11(2), 165-176.

Herrera, C.D., Pino Villalón, J.L., \& López Espinoza, M.A. (2020). Measuring internalized cultural capital: A scale for higher education. Revista Pedagogia Universitaria y Didactica del Derecho, $7(2), 299-323$.

Holovaty, M. (2014). Multiculturalism as a means of nations and countries interethnic unity achieving. Economic Annals-XXI, 11-12, 15-18.

Hryniak, A.B., Pleniuk, M.D., \& Lapko, A.H. (2021). Practical-oriented nature of learning as an important component of legal education reform in Ukraine. Journal of the National Academy of Legal Sciences of Ukraine, 28(3), 186-196.

Huidu, A. (2018). Redefining autonomy, dignity and intimacy in a postmodern society. Revista Romaneasca Pentru Educatie Multidimensionala, 10(3), 112-118.

Illman, V., \& Pietilä P. (2018). Multilingualism as a resource in the foreign language classroom. ELT Journal, 72(3), 237-248.

Ivanova, I., Mosenkis, I., \& Strokal, O. (2020). Modern media pedagogy: Ways of forming public journalism in Ukraine. Asia Life Sciences, 22(2), 357-370.

Kelly, J. (2002). Postmodernism and feminism: The road to nowhere. Marxism Against Postmodernism in Educational Theory, 34, 147-167.

Kiki-Papadakis, K., \& Chaimala, F. (2016). The embedment of responsible research and innovation aspects in european science curricula. Revista Romaneasca Pentru Educatie Multidimensionala, $8(2), 71-87$.

Köktürk, Ş. (2012). Forms and multifunctionality of interruptions and simultaneous speaking in ordinary talk - Proposal of a universal model for the evaluation of interruptive speech sequences. International Journal of Linguistics, 4(3), 551-571.

Kuzmina, M., Protas, O., Fartushok, T., Raievska, Y., \& Ivanova, I. (2020). Formation of students' competence of tertiary educational institutions by practical training aids. International Journal of Higher Education, 9(7), 279-288.

Lalak, N.V., \& Hrab, M.V. (2020). Current trends in education reform in Norway. Scientific Bulletin of Mukachevo State University. Series "Pedagogy and Psychology", 1(11), 229-232.

Lu, L. (2020). Design and implementation of an interactive information system for university education under the cloud service model. In IEEE Conference on Telecommunications, Optics and Computer Science (pp. 377-381). Piscataway: IEEE.

Mason, R. (2006). Learning technologies for adult continuing education. Studies in Continuing Education, 28(2), 121-133.

Melia, J.M.J., Bakieva, M., \& Sanchez-Delgado, P. (2020). Social cohesion as an objective of education: Can we specify a quality model for evaluation of educational sistems? Fronteiras, 9(3), 239-260.

100 Journal of Higher Education Theory and Practice Vol. 21(14) 2021 
Mirķe, E., Kašparová, E., \& Cakula, S. (2019). Adults' readiness for online learning in the czech republic and latvia (digital competence as a result of ICT education policy and information society development strategy). Periodicals of Engineering and Natural Sciences, 7(1), 205-215.

Mostepaniuk, A. (2020). The role of non-governmental organizations in the period of socio-economic transformation. Scientific Horizons, 6(91), 84-91.

Nepomnyashchyy, O.M., Marusheva, O.A., Prav, Yu.H., Medvedchuk, O.V., \& Lahunova, I.A. (2021). Certain aspects of the system of public administration of universities: World practices and the Ukrainian dimension. Journal of the National Academy of Legal Sciences of Ukraine, 28(1), 99105.

Rababah, I. (2020). The reality of using modern teaching methods in teaching arabic for speakers of other languages from teachers' perspective. Journal of Social Sciences, 9(1), 58-94.

Ramirez-Leal, P. (2020). Quantitative reasoning and written communication. Competencies that evidence scientific thinking in university graduates. Journal of Physics: Conference Series, 1674(1), Article number: 012015 .

Salgur, S.A. (2013). The importance of the teacher in intercultural education. International Journal of Global Education, 2(1), 1-5.

Savu, E. (2014). The "intercultural" teacher - a new response to the teaching career. Procedia - Social and Behavioral Sciences, 128, 111-116.

Sitsinska, M., Sitsinskiy, A., Nikolaiev, V., Khadzhyradieva, S., \& Hasiuk, I. (2021). Legal and socioeconomic aspects of reforming Ukraine's higher education system. Journal of the National Academy of Legal Sciences of Ukraine, 28(1), 88-98.

Synorub, H., \& Medynska, O. (2019). Development of information culture of students of humanitarian specialities. Information Technologies and Learning Tools, 72(4), 152-167.

Voinea, M. (2012). The role of intercultural education in defining the system of individual values. Procedia - Social and Behavioral Sciences, 33, 288-292.

World Economic Forum. (2020). The future of job report. Retrieved from http://www3.weforum.org/docs/WEF_Future_of_Jobs_2020.pdf?fbclid=IwAR1DLOZcdF4DWC ymmSYSGKB_DpkghMoZzqE-RwkȲ8gkdJ_SxZE3GH45tZz8

Zhernova, A. (2018). Information and communication technologies in higher education: Toward the preparedness of the subjects of education for innovation. Scientific Research in Social and Political Psychology, 33, 172-179. 